\title{
EFFECT OF DIFFERENT SOURCES OF PHOSPHORUS AND BIO FERTILIZERS ON YIELD AND SEEDS QUALITY OF SOYBEAN
}

\author{
Lamyaa A. Abd El-Rahman, Dalia A. Sayed and Magda A. Ewais \\ Soils, Water and Environ. Res., Institute, Agric. Res. Center, Giza, Egypt
}

Received: Nov. 25,2018

Accepted: Dec. 29, 2018

\begin{abstract}
Phosphorus $(P)$ is the second important key plant nutrient after nitrogen. An adequate supply of $P$ is therefore required for proper functioning and various metabolisms of plants. Majority of $P$ in soils is fixed and hence, plant available $P$ is scarcely available despite the abundance of both inorganic and organic $P$ forms in soils. A group of soil microorganisms capable of transforming insoluble $P$ into soluble and plant accessible forms across different genera, collectively called phosphate-solubilizing bacteria (PSB), have been found as best ecofriendly option for providing inexpensive $P$ to plants. These organisms in addition to supplying soluble $P$ to plants also facilitate the growth of plants by several other mechanisms, for instance, improving the uptake of nutrients and stimulating the production of some phytohormones.
\end{abstract}

Two field experiments were conducted at EL-Gemmiza, Agric. Res. Station, (30 47' 22.5" $\mathrm{N}, 31^{\circ}$ 07' 34" E, elev. $10 \mathrm{~m}$ ), Agric. Res. Centre., El-Gharbia Governorate, Egypt, during the two successive summer seasons of 2017 and 2018, to study the effect of different application sources and rates of phosphorus on the growth, productivity, yield characters and quality of soybean (Glycine max L.), c.v. Giza 111. The treatments consisted of four sources of phosphorus [single super phosphate (SSP), rock phosphate $(R P)$, single super phosphate (SSP) + phosphate solubilizing bacteria (PSB) and rock phosphate $(R P)+$ phosphate solubilizing bacteria (PSB)] at three levels of added P.i.e (0, 15 and $22.5 \mathrm{~kg} \mathrm{P}_{2} \mathrm{O}_{5} \mathrm{fed}^{-1}$ ). Results revealed that seed and straw yield and uptake of $N, P$ and $K$ increased significantly with both sources of $P$ over control. Application of single superphosphate proved superior increases compared to rock phosphate in respect of yield and uptake of nutrients. There was a significant increase in yield and uptake of nutrients with increase in $P$ application rate from $15 \mathrm{~kg} \mathrm{P}_{2} \mathrm{O}_{5}$ $\mathrm{fed}^{-1}$ to $22.5 \mathrm{~kg} \mathrm{P}_{2} \mathrm{O}_{5} \mathrm{fed}^{-1}$ applied either as SSP or RP. Protein content in soybean seed increased significantly with both the sources of $P$. The application of SSP $+P S B\left(T_{g}\right)$ recorded higher yield (grain and straw) and uptake of nutrients than phosphorus alone. The maximum seed (1572 kg/fed) and straw (4473.33 kg/fed) yields were recorded with $22.5 \mathrm{~kg} \mathrm{P}_{2} \mathrm{O}_{5} \mathrm{fed}^{-1}$ as SSP+PSB. Significant differences among the treatments were noticed with respect to number of pods per plant, seed yield per plant, test weight and seed yield. Application of $22.5 \mathrm{~kg}_{2} \mathrm{O}_{5} \mathrm{fed}^{-1}$ with PSB $\left(T_{9}\right)$ produced maximum number of pods/plant (150.67), seed yield (74.23 g/plant) and hundred seed weight (18.77 g/plant) as SSP and the lowest was in the control. Regarding evaluation of phosphorus use efficiency had more pronounced effects on combined application of SSP+PSB followed by RP+ PSB. Quality parameters viz., oil content, oil yield and crude protein content differ markedly among different treatments with the application of levels of phosphorus and bio-fertilizer.

Key words: phosphorus, single super and rock phosphate, Bio fertilizer, soybean yield and seeds quality.

INTRODUCTION

Soybean (Glycine max L.), is the most important pulse crop in the world. 
Soybeans serve as one of the most valuable crops in the world, not only as an oil seed crop and feed for livestock and aquaculture, but also as a good source of protein for the human diet and as a biofuel feedstock. World soybean production increased by $4.6 \%$ annually from 1961 to 2007 and reached average annual production of $\mathbf{2 1 7 . 6}$ million metric tons in 2005-07. World production of soybeans is predicted to increase by $\mathbf{2 . 2}$ $\%$ annually to 371 . 3 million metric tons by 2030 using an exponential smoothing model with a dampened trend (Masuda and Goldsmith, 2009). Soybean oil is used directly in food and preventing high blood pressure caused by arteriosclerosis. It also contains lot of the essential vitamins for the body. Soybean seed is a major source of protein, oil, carbohydrates, isoflavones, and minerals for humans and animals (Hou et al., 2009). Protein in soybean seed ranges from 34 to $57 \%$ of total seed weight, with a mean of $42 \%$. The oil content ranges from 8.3 to $28 \%$, with a mean of $19.5 \%$ (Wilson, 2004). The concentration of saturated fatty acids in soybean oil ranges from 10 to $12 \%$ palmitic acid (C16:0), and 2.2 to $7.2 \%$ stearic acid (C18:0) (Cherry et al., 1985). The mean concentration of unsaturated fatty acids in oil is $24 \%$ oleic acid (C18:1), $54 \%$ linoleic acid (C18:2), and $8.0 \%$ linolenic acid (C18:3) (Schnebly and Fehr, 1993). Higher oleic acid and lower linolenic acid are desirable traits for oil stability and long-term shelf storage. Another component of soybean seed composition is carbohydrates. Most of the carbohydrates are insoluble polysaccharides, including pectin, cellulose, hemicellulose, and starch (Liu, 1997). Soluble carbohydrates include monosaccharides (glucose and fructose), disaccharides (sucrose), and oligosaccharides (raffinose and stachyose) (Liu, 1997). Soybean seed contains 9 to $12 \%$ total soluble carbohydrates, which include 4 to $5 \%$ sucrose $\left(\mathrm{C}_{12} \mathrm{H}_{22} \mathrm{O}_{11}\right), 1$ to $2 \%$ raffinose $\left(\mathrm{C}_{18} \mathrm{H}_{32} \mathrm{O}_{16}\right)$, and 3.5 to $4.5 \%$ stachyose $\left(\mathrm{C}_{24} \mathrm{H}_{42} \mathrm{O}_{21}\right)$ (Wilson, 1995).

Under Egyptian soil conditions, phosphorus availability in soil is governed by many factors $\left(\mathrm{pH}, \mathrm{CaCO}_{3}\right.$, organic matter and clay contents). In spite of the considerable addition of $P$ to these soils, the level of available phosphorus decreases sharply after a short period from application (Miller et al., 1990). They revealed that under alkaline soil conditions, the available phosphorus in the added fertilizer are rapidly transformed to tricalcium phosphate thus becomes unavailable to the plants. Rock phosphate is the main source for producing phosphate fertilizers, where the total reserve source of rock phosphate in the world is about 128000 million tons. The direct application of apatite instead of phosphate fertilizers is not suitable, especially in the soils with height $\mathrm{pH}$. But however, using the acidic materials such as sulfur, sulfuric acid, etc. or using rock phosphate combined with microorganisms such as (phosphate dissolving bacteria), which can produce some acids, will release phosphorus from rock phosphate and can replace $P$ fertilizers.

Soil microorganisms play a key role in soil $P$ dynamics and subsequent availability of phosphate to plants (Richardson, 2001). Microbial community influences soil fertility through soil processes viz. decomposition, mineralization, and storage/release of nutrients. Microorganisms enhance the $P$ availability to plants by mineralizing organic $P$ in soil and by solubilizing precipitated phosphates (Chen et al., 2006). Release of $P$ by PSB from insoluble and fixed/adsorbed forms is an import aspect regarding $P$ availability in soils. There are strong evidences that soil bacteria are capable of transforming 
soil $P$ to the forms available to plant. Microbial biomass assimilates soluble $P$, and prevents it from adsorption or fixation (Khan and Joergesen, 2009). Nutritional capacity of single super phosphate (SSP) or rock phosphate (RP) were further improved by PSB inoculation due to its ability to convert sparingly soluble inorganic phosphate into soluble forms by secreting organic acids. Microorganisms through secretion of different types of organic acids like carboxylic acid (Deubel and Merbach ,2005) and rhizosphere $\mathrm{pH}$ lowering mechanisms dissociate the bound forms of phosphate like $\mathrm{Ca}_{3}\left(\mathrm{PO}_{4}\right)_{2}$. Among various factors that can contribute to soybean success, phosphorus and inoculation had quite prominent effects on nodulation, growth and yield parameters (Kumaga and Ofori, 2004). It is well known that more than two-third of phosphatic fertilizers are render unavailable within a very short period of time after its application due to fixation in soil complex as di and tri-calcium phosphate (Afzal et al., 2005). Application of phosphorus along with phosphate solubilizing bacteria (PSB) improved phosphorus uptake by plants and yields indicating that the PSB are able to solubilize phosphates and to mobilize phosphorus in crop plants (Deubel and
Merbach 2005). In this respect, bio fertilization technology has taken a part to minimize production costs and at the same time avoid the environmental hazards (Galal et al., 2001). Therefore, the present study was conducted to examine the effect of PSB with $P$ soluble fertilizer (SSP) and insoluble rock phosphate (RP) on yield attributes, yield and quality of seed and efficiency of phosphorus in soybean.

\section{MATERIALS AND METHODS}

Two field experiments were conducted at EL-Gemmiza, Agric. Res. Station, (30ㅇ 47' 22.5" N, 31 07' 34" E, elev. $10 \mathrm{~m}$ ), Agric. Res. Centre, El-Gharbia Governorate, Egypt, during the two successive summer seasons of 2017 and 2018, to study the effect of different application sources and rates of phosphorus on yield attributes, yield and quality of soybean seeds (Glycine max L.), c.v. Giza 111. as well as the effect of bio-fertilizer on the efficiency of phosphorus fertilizers. Representative soil surface sample $(0-30 \mathrm{~cm})$ was taken from the experimental site before sowing and prepared to determine some physical and chemical properties according to the methods described by Page et al., (1982) and Klute, (1986) and the obtained are shown in Table

(1).

Table (1): Physical and chemical characteristics of the soils under investigation a) Physical analysis

\begin{tabular}{|c|c|c|c|c|c|c|}
\hline \multirow{2}{*}{$\mathrm{CaCO}_{3}(\%)$} & \multirow{2}{*}{ OM (\%) } & \multicolumn{4}{|c|}{ Particle size distribution (\%) } & \multirow{2}{*}{ Texture class } \\
\cline { 3 - 6 } & & $\begin{array}{c}\text { Course } \\
\text { Sand }\end{array}$ & $\begin{array}{c}\text { Fine } \\
\text { Sand }\end{array}$ & Silt & Clay & \\
\hline 1.89 & 2.06 & 2.11 & 13.65 & 45.4 & 38.85 & Clay loam \\
\hline
\end{tabular}

b) Chemical analysis

\begin{tabular}{|c|c|c|c|c|c|c|c|c|c|c|c|c|}
\hline $\begin{array}{c}\mathrm{pH} \\
(1: 2.5)\end{array}$ & $\begin{array}{c}\mathrm{ECe} \\
(\mathrm{dSm}-1)\end{array}$ & \multicolumn{8}{|c|}{ Soluble ions in soil paste extract $\left(\mathrm{meqL}^{-1}\right)$} & \multirow{2}{*}{\multicolumn{3}{|c|}{$\begin{array}{c}\text { Available } \\
\text { nutrients } \\
\left(\mu \mathrm{g} \mathrm{g}^{-1}\right)\end{array}$}} \\
\hline $\begin{array}{l}\text { Soil: Water } \\
\text { Suspension }\end{array}$ & $\begin{array}{l}\text { Soll } \\
\text { paste }\end{array}$ & \multicolumn{4}{|c|}{ Cations } & \multicolumn{4}{|c|}{ Anions } & & & \\
\hline 7.85 & 2.15 & $\mathrm{Na}^{+}$ & $\mathrm{K}^{+}$ & $\mathrm{Ca}^{2+}$ & $\mathbf{M g}^{2+}$ & $\mathrm{CO}_{3}^{-}$ & $\mathrm{HCO}_{3}^{-}$ & $\mathrm{Cl}^{-}$ & $\mathrm{SO}_{4}{ }^{2-}$ & $\mathbf{N}$ & $\mathbf{P}$ & K \\
\hline
\end{tabular}


Lamyaa A. Abd El-Rahman, et al.,

\begin{tabular}{|l|l|l|l|l|l|l|l|l|l|l|l|l|}
\hline & & 8.38 & 2.04 & 6.23 & 5.42 & - & 9.45 & 8.59 & 4.02 & 72 & 9.3 & 429 \\
\hline
\end{tabular}

\section{Experimental design}

The studied treatments were arranged within the experiment in two-factor randomized block design with three replications. Each experiment included 12 treatments. The experimental unit area was $10.5 \mathrm{~m}^{2}$ consisting of five rows $(3.5$ $\mathrm{m}$ long and $60 \mathrm{~cm}$ between row). The distance between hills was $10 \mathrm{~cm}$ apart, each hill was planted by three seeds of soybean and after 15 days of planting thinned to two plants per hill. In this study four treatments of two sources of phosphorus i.e. single super phosphate (SSP), rock phosphate (RP), single super phosphate (SSP) + phosphate solubilizing bacteria (PSB) and rock phosphate (RP)+ phosphate solubilizing bacteria (PSB) were used. Phosphorus fertilizers were added at a rate of 15 and $22.5 \mathrm{~kg} \mathrm{P}_{2} \mathrm{O}_{5}$ fed $^{-1}$ plus the control treatment (without any fertilizer and PSB). The phosphorus treatments were applied manually before sowing with soil preparation

Nitrogen fertilizer was applied to all experimental units in the form of ammonium sulphate $(20.5 \mathrm{~N} \%)$ at a rate of $30 \mathrm{~kg} \mathrm{~N} / \mathrm{fed}$ in two equal doses before the first and second irrigations. Also, potassium sulphate $\left(\begin{array}{llll}48 & \% & K_{2} O\end{array}\right)$ was applied as potassium fertilizer at rate of $50 \mathrm{~kg} \mathrm{~K} \mathrm{~K}_{2} \mathrm{O} / \mathrm{fed}$.in two doses at the same time of $\mathbf{N}$ fertilizer applications. Before sowing the seed were treated with Rhizobium culture (Rhizobium japonicum $5 \mathrm{~g} / \mathrm{kg}$ seed) and phosphate solubilizing bacteria (Strains from the genera Pseudomonas) at $5 \quad \mathrm{~g}^{\mathrm{kg}^{-1}}$ seed. Agronomic practices were followed according to the standard recommendation for soybean.

At maturity stage and before harvesting the tested vegetative growth parameters i.e. plant height and number of pods plant ${ }^{-1}$ were carried out on ten plants selected randomly from each replicates. Then the plants of each replicate were harvested and divided into seeds and straw and prepared for the studied determinations.

\section{Yield and Its component characteristics}

Yield and its components such as plant height, number of pods plant ${ }^{-1}$, seed yield per plant, hundred seed weight, seed and stover yield were determined at maturity stage.

\section{Chemical analysis}

a- Seed samples were taken randomly from the samples of each replicate and oven-dried at $70{ }^{\circ} \mathrm{C}$ for $48 \mathrm{hrs}$ where it is used to determine $\mathrm{N}, \mathrm{P}$ and $\mathrm{K}$ contents. A $0.5 \mathrm{~g}$ of oven-dried soybean seeds of each replicate was digested in a $5 \mathrm{ml}$ of $\mathrm{H}_{2} \mathrm{SO}_{4} \cdot \mathrm{HClO}_{4}$ mixture (3:1 ratio) on sand plate at 250 ${ }^{\circ} \mathrm{C}$ according to the methods described by Chapman and Pratt, (1978). The final clear digestion diluted up to $50 \mathrm{ml}$ using distilled water and analyzed for its content of $N, P$ and $K$ as follows:

- Nitrogen (N) content in the digested of soybean seeds was determined by Keldahl method as described by A.O.A.C. (1990). Protein content in the seeds was calculated by multiplying $\mathrm{N} \%$ by 6.25 factor (A.O.A.C., 1990).

-Phosphorus (P) was determined calorimetrically according to the methods described by Chapman and Pratt (1978).

-Potassium (K) was determined by flam photometer according to Page et al., (1982).

\section{b- Nutrient uptake}


Nutrient uptake was calculated by multiplying the $\mathrm{N}, \mathrm{P}$ and $\mathrm{K}$ concentration of soybean seed and P-uptake in stover with their respective yield.

C- Other sample of soybean seeds, oil content (\%) was determined by soxhelt apparatus using hexane as a solvent as described by A.O.A.C. (1990). Oil and protein yield (kg/fed.) were estimated by multiplying seed yield ( $\mathrm{kg} / \mathrm{fed}$.) by seed oil and protein percentages respectively. Protein and oil concentrations were expressed on a oven-dry seed basis.

Soybean seed oil obtained from each sample was analyzed to determine the relative composition of different fatty acids (palmitic, stearic, oleic, linoleic, and linolenic acids) with gas chromatography fatty acid analyzer according to A.O.A.C. (1990).

\section{d- Phosphorus fertilizers efficiency}

Physiological Efficiency of $P\left(\mathrm{~kg} \mathrm{~kg}^{-1}\right)=$ (yield $F$ - yield $C$ )/ (P uptake F-P uptake C)

$$
\begin{aligned}
& \text { Where, } \text { F } \\
& \text { C }=\text { Fertilizer applied } \\
& \text { Control (without fertilizer). }
\end{aligned}
$$

Phosphorus use efficiency (PUE) was calculated as per Goodroad and Jellum (1988).

\section{- Statistical analysis}

The obtained results were statistically analyzed according to Gomez and Gomez (1984) to define the statistical significance of L.S.D. at $\mathbf{0 . 0 5}$.

\section{RESULTS AND DISCUSSION}

Effect of phosphorus fertilizer sources on yield and its attributes

The data of yield attributes listed in Table (2) viz., plant height, number of pods plant $^{-1}$, seed yield per plant and hundred seed weight indicated that, there are a significant differences within their yield characters according to the used $P$ source and its application. Highest plant height $(139.67 \mathrm{~cm})$ was recorded with the treatment of higher rate of phosphorus $\left(22.5 \mathrm{~kg} \mathrm{P}_{2} \mathrm{O}_{5} \mathrm{fed}^{-1}\right)$ as SSP + PSB and the lowest $(91.49 \mathrm{~cm})$ was obtained with the control treatment. Also, sources of phosphorus have a significant influence on different yield attributing characteristics of soybean like number of pods plant $^{-1}$, and hundred seed weight. Highest number of pods plant ${ }^{-1}$ (150.67) was recorded from the treatment of SSP+PSB and the lowest (72.33) was obtained from the control. Highest seed yield per plant $(74.23 \mathrm{~g})$ was recorded by application $22.5 \mathrm{~kg} \mathrm{P}_{2} \mathrm{O}_{5}$ fed $^{-1}$ of SSP with PSB followed by RP + PSB (62.79g) followed by application of $22.5 \mathrm{~kg} \mathrm{P}_{2} \mathrm{O}_{5}$ fed $^{-1}$ of SSP $(55.33 \mathrm{~g})$ as compared to control treatment $(35.64 \mathrm{~g})$. These findings means that application of single superphosphate has a superior and increased effect on yield parameters compared to rock phosphate. So, SSP considered a good $P$ source compared to rock phosphate sources at early growth stages which attributed to readily available $P$ resulting in better absorption and utilization of $\mathbf{P}$ by plant and presence of other important plant nutrient i.e. sulphur in the form of gypsum. Sulphur, besides increasing $P$ availability, also increases its assimilation rate (Abou Hussien et al., 2017). However, at later growth, increasing dissolution rate of RP through increased activities of soil microorganisms and plant related $\mathrm{pH}$ changes in rhizosphere owing to excretion of organic acids by roots and microorganisms might have enhanced $P$ dissolution and subsequent absorption for proper growth by chelating cationic partner of $P$ ions (Zaidi et al.,2009b).The increased plant height, number of pods plant $^{-1}$, seed yield per plant and hundred seed weight were mainly due to the improvement of phosphorus in several energy transformations and biochemical reactions including nitrogen fixation 
(Ahmed et al., 2015). Root development, stalk and stem strength and nitrogen fixation in legumes are the attributes associated with phosphorus nutrition. It shows that phosphorus is needed in relatively large amounts by legumes for growth and nitrogen fixation and it has been reported to promote biomass yield, nodule number, nodule mass etc., in a number of legumes (Ali et al., 2014). The increased plant height might be due to microorganisms with phosphate solubilisation and increasing the availability of soluble phosphate and enhancing the plant growth by improving biological nitrogen fixation. Similar results were reported by Tomar et al., (2004) and Qasim Shahid et al., (2009).
Further, Sharma et al., (2002), reported that positive improvement in growth parameters under different sources of phosphorus application might be due to increased metabolic process in plants resulting into greater meristematic activities and apical growth there by improving plant height, branches per plant and ultimately resulted in improved dry matter accumulation. Similarly, hundred seed weight was also maximum treated with SSP + PSB (18.77g) followed by RP + PSB (17.87g) and the lowest (14.33g) was obtained from the control. Recently, Abdel-hamid, (2018) obtained on similar results with soybean plants fertilized by $P$ and other mineral and biofertilizers.

Table (2): Effect of sources and levels of phosphorus on plant height and yield attributes of soybean (average of two years)

\begin{tabular}{|c|c|c|c|c|c|}
\hline & Treatments & Plant heiaht & Pods/plant & 100-seed & Seed yield \\
\hline P sources & P levels (kg P2O5/fed & & & & \\
\hline & $0 \mathrm{KgP2O5/fed}$ & 91.49 & 72.33 & 14.33 & 35.87 \\
\hline SSP & $15 \mathrm{KgP} 2 \mathrm{O} 5 / \mathrm{fed}$ & 118.00 & 86.67 & 15.73 & 49.00 \\
\hline & $22.5 \mathrm{KgP} 205 / \mathrm{fed}$ & 127.67 & 103.33 & 17.43 & 55.33 \\
\hline & Mean & 112.38 & 87.44 & 15.83 & 46.73 \\
\hline & $0 \mathrm{KgP2O5/fed}$ & 91.59 & 72.67 & 14.47 & 35.3 \\
\hline $\mathbf{R p}$ & $15 \mathrm{KgP} 205 / \mathrm{fed}$ & 114.67 & 81.00 & 16.30 & 44 \\
\hline & $22.5 \mathrm{KgP} 205 / \mathrm{fed}$ & 121 & 92.33 & 16.57 & 48.02 \\
\hline & Mean & 109.08 & 82.00 & 15.78 & 42.44 \\
\hline & $0 \mathrm{KgP2O5/fed}$ & 91.62 & 73.00 & 14.30 & 36.2 \\
\hline $\begin{array}{ll}\text { SST+ } \\
\text { PSR }\end{array}$ & $15 \mathrm{KgP2O} / \mathrm{fed}$ & 131.67 & 127.67 & 17.53 & 67.4 \\
\hline & $22.5 \mathrm{KgP} 2 \mathrm{O} 5 / \mathrm{fed}$ & 139.67 & 150.67 & 18.77 & 74.23 \\
\hline & Mean & 120.98 & 117.11 & 16.87 & 59.28 \\
\hline & $0 \mathrm{KgP2O5/fed}$ & 91.82 & 72.67 & 14.4 & 35.20 \\
\hline $\begin{array}{ll}\mathrm{Kp}+ \\
\mathrm{PSP}\end{array}$ & $15 \mathrm{KgP} 205 / \mathrm{fed}$ & 128.67 & 104.33 & 17.2 & 57.33 \\
\hline & $22.5 \mathrm{KgP} 205 / \mathrm{fed}$ & 133.33 & 119.67 & 17.87 & 62.79 \\
\hline & Mean & 117.94 & 98.89 & 16.49 & 51.77 \\
\hline Mnan & $0 \mathrm{KgP2O5/fed}$ & 91.63 & 72.67 & 14.38 & 35.64 \\
\hline Nor & $15 \mathrm{KgP} 2 \mathrm{O} / \mathrm{fed}$ & 123.25 & 99.92 & 16.69 & 54.43 \\
\hline
\end{tabular}


Effect of different sources of phosphorus and Bio fertilizers on yield and ............

\begin{tabular}{|c|l|c|c|c|c|}
\hline & $22.5 K g P 2 O 5 / f e d$ & 130.42 & 116.5 & 17.66 & 60.09 \\
\hline \multirow{2}{*}{$\begin{array}{c}\text { LSD at } \\
5 \%\end{array}$} & P sources & 5.63 & 13.79 & 0.63 & 3.73 \\
\cline { 2 - 7 } & P levels (kg P2O5/fed & 4.88 & 11.94 & 0.55 & 3.23 \\
\cline { 2 - 6 } & Interaction & n.s & 23.88 & n.s & 6.47 \\
\hline
\end{tabular}

The seed and straw yields of soybean increased significantly as a result of increase application rates of added $P$ in different sources as shown in Table (3) and Fig (1). Application of $22.5 \mathrm{~kg} \mathrm{P}_{2} \mathrm{O}_{5}$ $\mathrm{fed}^{-1}$ as SSP recorded a significant and higher seeds and straw yields than those fertilized with RP. The increases in seed and straw yields with $22.5 \mathrm{~kg} \mathrm{P}_{2} \mathrm{O}_{5}$ fed $^{-1}$ as SSP were 59.20 and $50.05 \%$, respectively over control. The increase in yield may be attributed to the effective metabolic activities coupled with increased rate of photosynthesis, leading to better translocation of nutrients and expression of development characters (El-Meslawy, 2014). The increases in seed and straw yields with $22.5 \mathrm{~kg} \mathrm{P}_{2} \mathrm{O}_{5}$ fed $^{-1}$ as SSP+ PSB were 83.16 and $66.48 \%$, respectively over control followed by the treatment of RP+ PSB at the same application rate, where it increased the seed and straw yield by 66.06 and $57.72 \%$ respectively over control. The $P$ solubilizing capacity of PSB is well known fact, which helps in increasing the release of $P$ from $R P$ and thus, maintains a steady $P$ supply to soybean plants under $P$ deficient conditions and subsequently improve the yield (EIMeslawy, 2014). Highest seed yield (1572 $\left.\mathrm{kg} \mathrm{fed}^{-1}\right)$, stover yield (4473.33 kg fed $\left.{ }^{-1}\right)$ and pods weight(2654.76) were recorded significantly due to application of higher level of phosphorus in combination with PSS (22.5 kg $\mathrm{P}_{2} \mathrm{O}_{5}$ fed $^{-1}+$ PSB) as shown from the data of $T_{9}$, where the found yields $\left(1572,4473.33\right.$ and $2654.76 \mathrm{~kg} \mathrm{fed}^{-1}$ ) respectively followed by those associated the treatment RP+ PSB of treatment $T_{12}(1417,4343$ and $2540.33 \mathrm{~kg}$ $\mathrm{fed}^{-1}$ ) respectively. The beneficial effect of phosphorus application on seed yield attributes resulting ultimately yield fed $^{-1}$ as phosphorus play a specific role in increase the ratio of grain to stover. It is essential to reproductive functions; stimulates early root growth, enhances the activity of rhizobia and root nodules, synthesis of protein and amino acid of pulse crop. Thus, phosphorus has been identified as an essential primary nutrient (Marschener, 2003). As regards the sources of phosphorus, an application of single superphosphate has a superior effect over rock phosphate. The superiority of single superphosphate as phosphorus fertilizer may be attributed to increased availability of phosphorus and increased availability of other nutrients particularly calcium $(20 \%)$ in presence of sulphur (12\%). This might be due to the cumulative favorable effect of higher number of pods plant $^{-1}$ and higher hundred seed weight (Table 2). Phosphorus has important effects on photosynthesis, nitrogen fixation, root development, flowering, seed formation, fruiting and improvement of crop quality (Brady, 2002). Phosphate solubilizing bacteria enhance the phosphorus availability to plants by mineralizing organic $P$ in soil and by solubilizing precipitated phosphate (Chen, et al., 2006). Cao et al., (2017) have also reported significant increases in seed yield of soybean due to co-inoculation of phosphorus solubilizes. Higher crop yields resulted from solubilization of fixed soil $P$ and applied phosphates by PSB (Chen et al., 2006). Inoculation with phosphate-solubilizing bacteria (PSB) may help to solubilize native soil $P$ as well as $P$ from rock phosphates for plant uptake. Solubilization of phosphorus by these phosphate solubilizing 


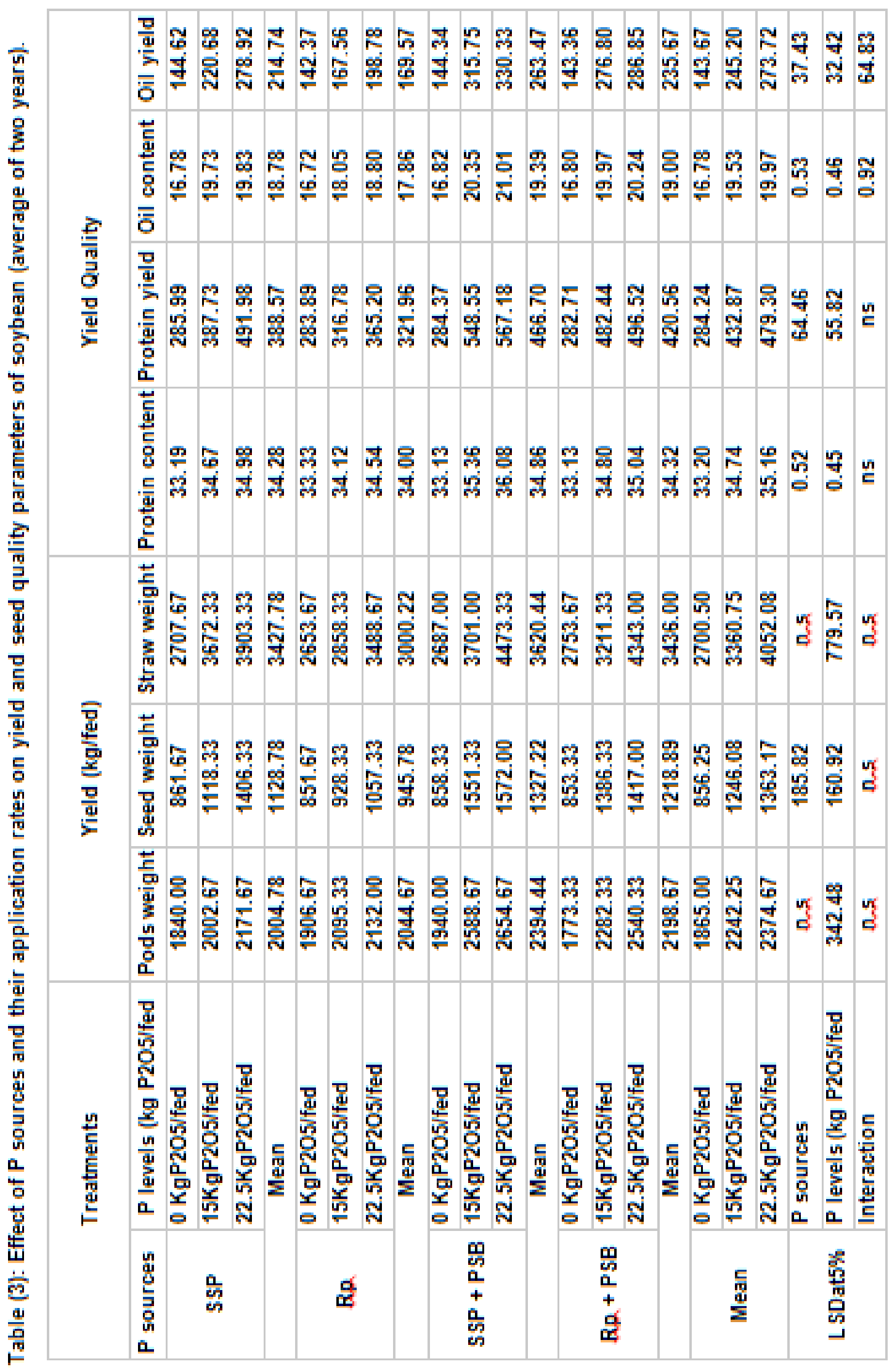


excretion of organic acids like glutamic, succinic, lactic, oxalic, glyoxalic, maleic, fumaric, tartaric, alpha - ketobutyric, propionic and formic acid. Some of these acids (hydroxy acids) may form chelation with cations such as $\mathrm{Ca}^{2+}$ and $\mathrm{Fe}^{2+}$, which result in effective solubilization of phosphates. Inoculations of $P$ solubilizing microorganisms have shown to enhance $P$ uptake and yields of soybean. Utilizing such efficient of $P$ solubilizing bio fertilizers have been developed and are 


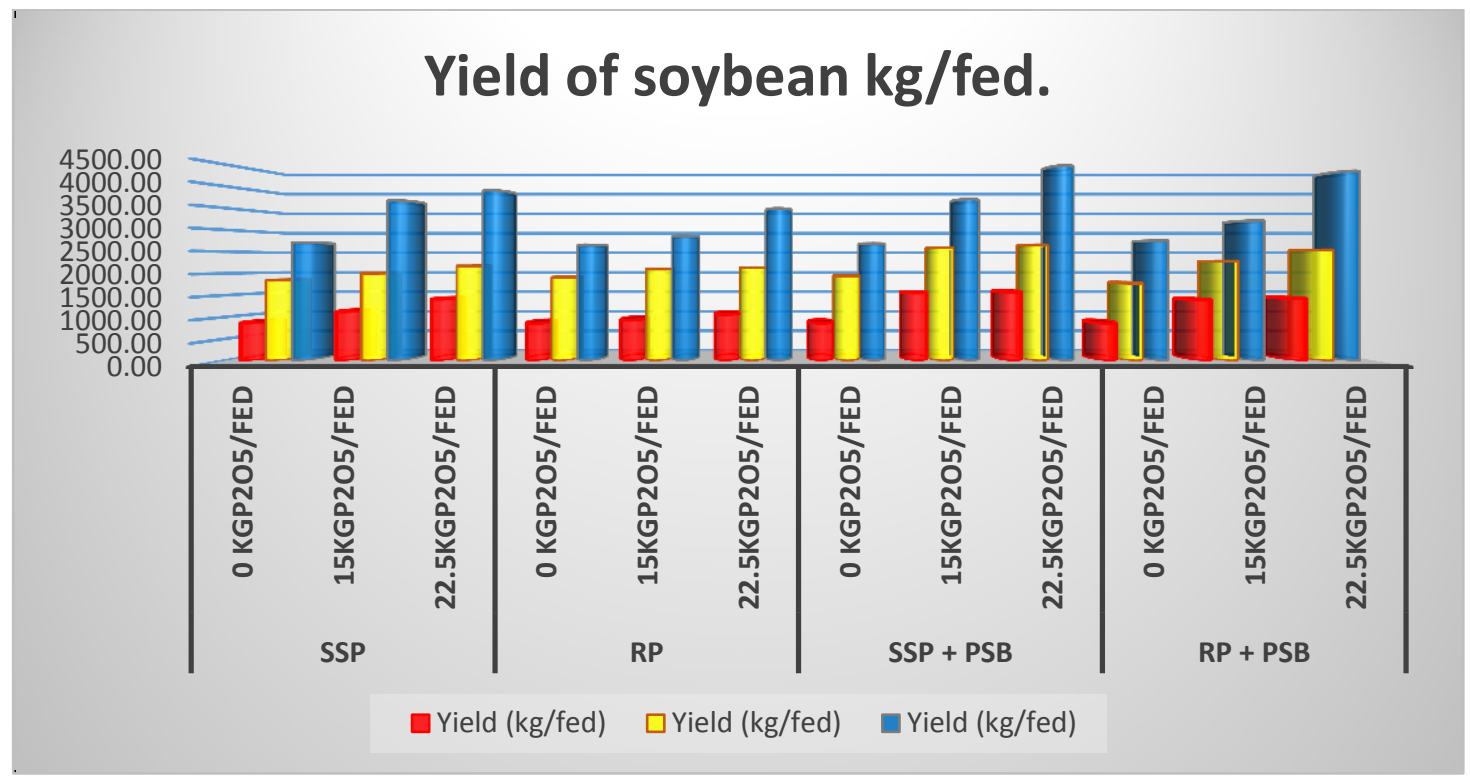

Fig. (1): Effect of $P$ sources and their application rates on seeds, straw and pods of soybean

gaining popularity. The maximum stover yield $\left(4473.33 \mathrm{~kg} \mathrm{fed}^{-1}\right)$ was obtained from the treatment of SSP + PSB especially at application rate of $22.5 \mathrm{~kg} \mathrm{fed}^{-1}$ and the lowest one $\left(2700.50 \mathrm{~kg} \mathrm{fed}^{-1}\right)$ was obtained from the control. This might be due to the combine effect of SSP +PSB, which contains both phosphorus and phosphate solubilizing bacteria as well as enhancement of phosphorus availability to plants by mineralizing organic phosphorus in soil and by solubilizing precipitated phosphates (EIMeslawy, 2014). Data in the present study clearly indicated that rock phosphate when used in combination with microbial treatments was transformed into available forms of $P$ which reflected on the increase of $P$ uptake by growth of soybean plants (Table 2).
Effect of $P$ sources and their application rates on yield and its attributes

Different levels of application of phosphorus significantly increased yield attributing characteristics i.e. plant height, number of pods plant $^{-1}$ and hundred seed weight of soybean. Application of SSP at a rate of $22.5 \mathrm{~kg}$ $\mathrm{P}_{2} \mathrm{O}_{5}$ fed $^{-1}$ in combination with PSB produced maximum number of pods plant $^{-1}(150.67)$ and hundred seed weight $(18.77 \mathrm{~g})$ and the lowest was obtained from the control (Table 2). Seed and stover yield of soybean was also increased significantly with increasing rates of phosphorus fertilizer. The maximum seed yield (1406.33 kg/fed) produced by the application of $22.5 \mathrm{~kg}$ $\mathrm{P}_{2} \mathrm{O}_{5}$ fed $^{-1}$ as SSP. Such positive improvement in growth parameters under increased $P$ application might be due to increased metabolic processes in plants 
resulting greater meristematic activities and apical growth thereby improving plant height, branches/plant and higher number of leaves/plant ultimately resulted in improved dry matter accumulation (Marschener, 2003). Phosphorus deficiency has been shown to restrict severely the nodulation process in soybean. Phosphorus has specific role in nodule initiation, growth and function in addition to its role in host plant growth. The increase in seed yield might be due to more number of pods plant $^{-1}$, seeds pod $^{-1}$ and/or hundred seed weight. The low yield of soybean seed at lower levels of phosphorus and control was probably due to lesser magnitude of phosphorus response. The improvement in seed and stover yield at higher levels of phosphorus may be attributed to the role of phosphorus in the negotiation processes, profuse nodulation and being the constituent of ribonucleic acid, deoxyribonucleic acid and ATP which regulate vital metabolic processes in the plant. Further, it also helps in root formation and nitrogen fixation results in positive effect on photosynthetic organs and rate which in turn favors better growth and yield of the crop (Basak, 2006). The results are in conformity with that of, Ilbas and Sahn (2005); Jain and Trivedi (2005), Tapas and Gupta (2005), Tomar et al. (2006) in soybean and Erman et al. (2009) in field pea. In addition on, results in Table (2) and Fig. (1) showed that seed yield of soybean increased with inoculation and applying higher levels of phosphorus. Higher crop yields resulted from solubilization of fixed soil $P$ and applied phosphates by PSB (Chen et al., 2006 and El-Meslawy, 2014). The maximum stover yield might be due to the combine effect of applied nutrients through fertilizers as well as enhancement of phosphorus availability to plants by mineralizing organic phosphorus in soil and by solubilizing precipitated phosphates. The most important mechanism which is usually involved in phosphate solubilization is production of organic acids.

The results indicated interaction between sources and application rates of $P$ have a significant increases on seeds and straw yields as well as the weight of 100 seeds (Table 2 and 3 ). Also, this treatment showed a significant effect on the increase of number of pods/plant. Inoculations by PSB with rock phosphate application further increased the yield and were comparable with the treatment receiving super phosphate alone, indicating the possibility of replacing the super phosphate with rock phosphate. Sources of phosphorus significantly influenced the growth and yield parameter (EI-Meslawy, 2014).

Effect of $P$ sources and their application rates on quality parameters Protein and oil content

Quality of protein and oil content depicted in (Table 3) were improved significantly by the application of higher added levels and sources of phosphorus. The increases in protein and oil content were 5.58 and $18.18 \%$ at application on rate of $22.5 \mathrm{~kg} \mathrm{P}_{2} \mathrm{O}_{5} \mathrm{fed}^{-1}$ as SSP respectively over the control followed by RP i.e.3.63 and $12.44 \%$ over the control treatment. This means that, the high quality of soybean seeds were found with the high rate of added $P$ those found with the treatment of $\left(22.5 \mathrm{~kg} \mathrm{P} \mathrm{P}_{2} \mathrm{O}_{5}\right.$ fed). The increase in oil content with $P$ application could be due to the fact that $P$ helped in synthesis of fatty acids and their esterification by accelerating biochemical reactions in glyoxalate cycle (Dwivedi and Bapat, 1998). The maximum protein and oil content were recorded with a treatment combination of $22.5 \mathrm{~kg} \mathrm{P}_{2} \mathrm{O}_{5}$ fed $^{-1}$ with phosphate solubilization. The increase in protein content with $P$ application might be due to higher $N$ uptake as a result of increased 
nodulation and $\mathrm{N}$ fixation by nodules (Singh et al., 2014).

\section{Protein and oil yield}

The protein and oil yields of soybean seeds were increased significantly as a result of added different sources of $P$ (Table 3) and Fig. (2 and 3). Maximum yield of Protein was found with the treatment of $22.5 \mathrm{~kg} \mathrm{P} \mathrm{O}_{5} / \mathrm{fed}$ of either
SSP or RP with PSB compared of $15 \mathrm{~kg}$ $\mathrm{P}_{2} \mathrm{O}_{5} / \mathrm{fed}$ and control. This could be ascribed due to protein content is essentially the manifestation of $\mathbf{N}$ concentration in seed. Hence, increased $\mathrm{N}$ concentration might have increased the protein content and finally protein yield (Abdel-hamid, 2018).

\section{protein yieldkg/fed}

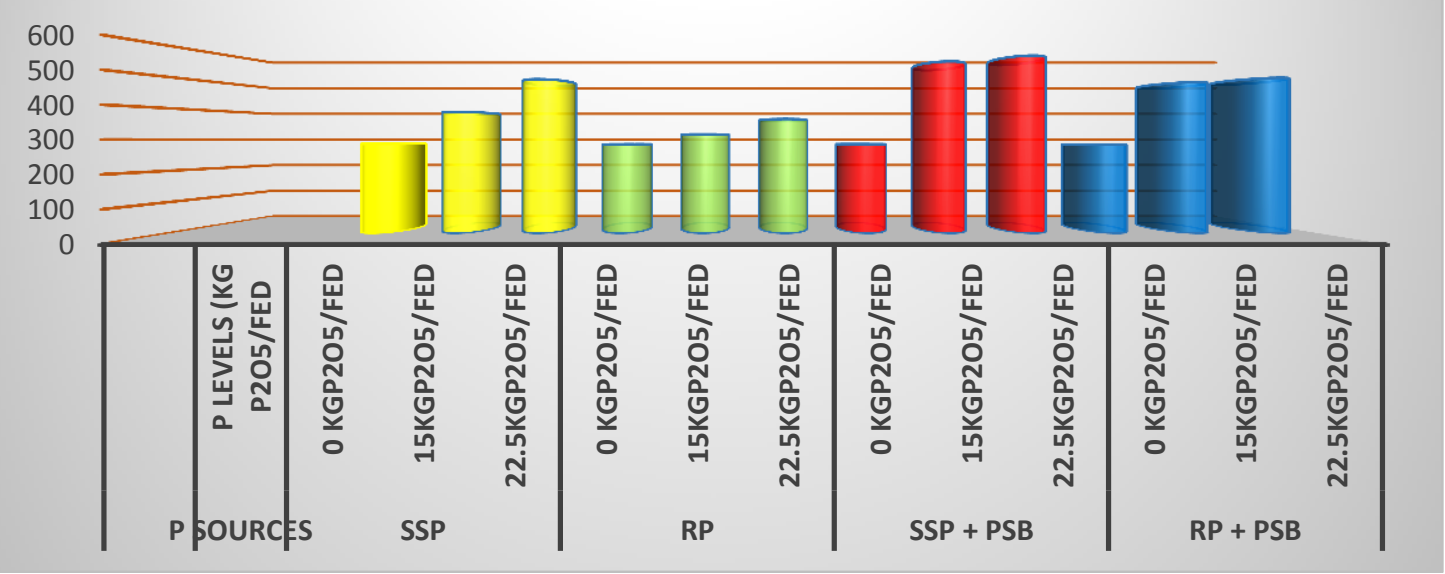

Fig. (2): Effect of P sources and their application rates on protein yield of soybean seeds.

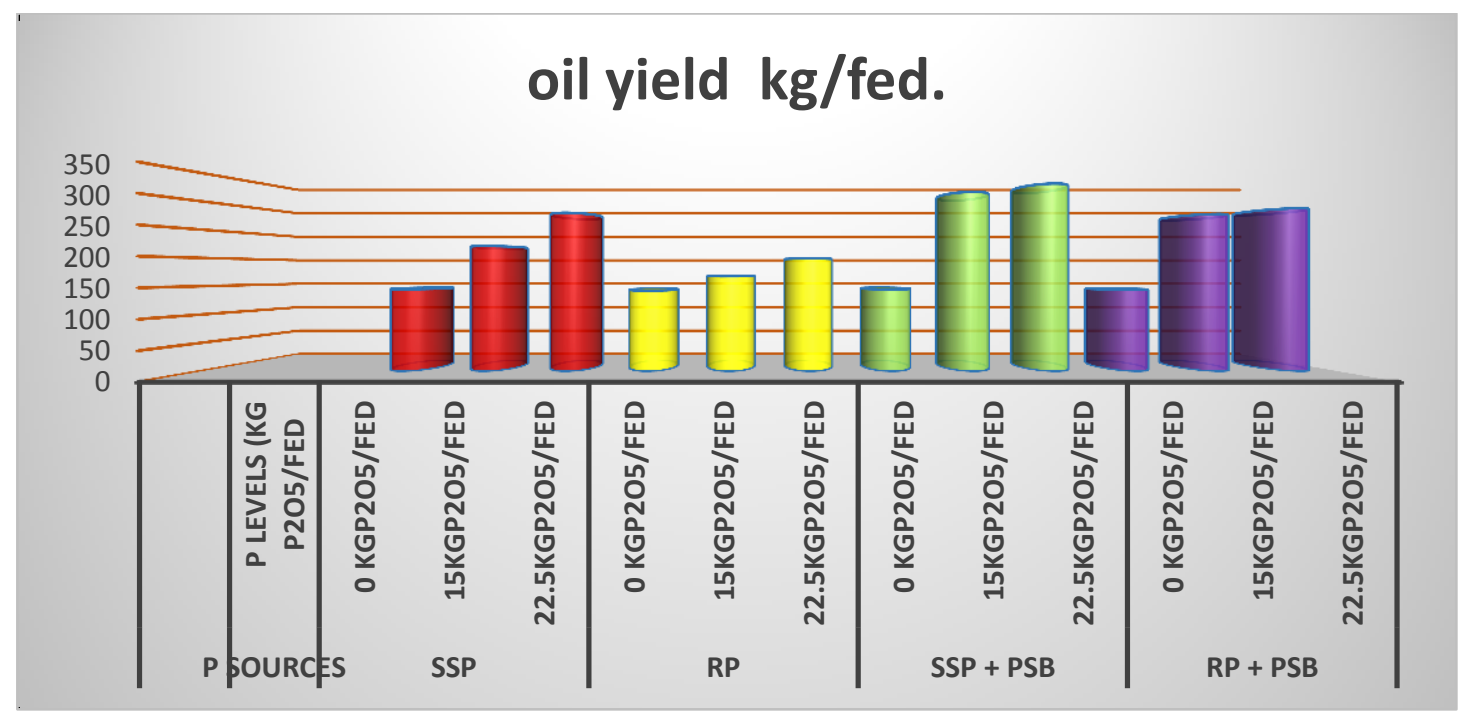

Fig. (3): Effect of $P$ sources and their application rates on oil yield of soybean seeds.

These results corroborated with the finding of Jain et al., (2007) and Singh and Singh (2012b). Further data showed that higher oil content $(21.01 \%)$, and protein content $(36.08 \%)$ were recorded in SSP+PSB. This might be due to the presence of sulphur in SSP, which is involved in the synthesis of fatty acids 
and also increase protein quality through the synthesis of certain amino acids such as cysteine and methionine. It is evident from the results that sulphur had remarkable influence on oil and protein content. Similar findings were also reported by Havlin et al., (1999) and Kandpal and Chandel (1993). Phosphate solubilizing bacteria also are capable of transforming soil phosphorus to the forms available to plant (EI-Meslawy, 2014).

\section{Effect of application rates of $P$ on quality parameters of soybean seeds}

Protein content and yield of soybean seeds were increased significantly with the increase of added $P$ different sources as shown in Table (3) and Fig. (2). The maximum protein content was found $(36.08 \%)$ with the application of $22.5 \mathrm{~kg}$ $\mathrm{P}_{2} \mathrm{O}_{5} / \mathrm{fed}$. There are a significant difference within the found increases of protein content resulted from different rates of added P. Higher $P$ fertilization was necessary for higher protein content in soybean seed as well as protein yields (Shah et al., 2002). This might be due to the plants absorbed plant nutrients relatively in higher quantity because the pool of available phosphorus was already increased doses of applied phosphorus resulting enhancement of growth and yield attributes of crop (Basak, 2006). It is well known that $P$ deficiency reduces soybean leaf area and the number of leaves, nodes, and branches; P-deficient plants exhibit reduced carbohydrate supply to nodules and decreased nodule weight, number, and functioning, such as reduced nitrogenase activity of the nodule. Therefore, $P$ fertilization increases $\mathrm{N}$ fixation in soybean and thus enhances protein concentration in soybean seed. All treatments containing $P$ source along with the bio fertilizers recorded similar results. This may be due to high $P$ availability caused by solubilisation and mobilization by PSB (El-Meslawy, 2014). Microbial community influences soil fertility through soil processes, viz. decomposition, mineralization, and storage/ release of nutrients. Microorganisms enhance the $P$ availability by mineralizing organic $P$ in soil and by solubilizing precipitated phosphates (Chen et al., 2006).

Oil content and yield of soybean seeds were increased significantly as a result of $P$ application as well as bio fertilizers (Table 3). Similar results were obtained by Yin et al (2016), who found that application of chemical fertilizers such as phosphorus increased the seed oil content and oil yield per hectare over the control in soybean. This may be attributed to phosphorus, required for production of high quality seeds, where it occurs as co-enzyme involved in energy transfer reaction so that energy is trapped in photosynthesis in form of adenosine triphosphate (ATP) and nicotinamide adenine dinucleotide phosphate (NADP) which is subsequently used in photosynthetic fixation of $\mathrm{CO}_{2}$ and the synthesis of lipids and other essential organic compounds (Taiz and Zeiger, 1991).

Fatty acid composition of seed lipid is an important determinant of oil quality. Soybean oil is highly demanding worldwide in terms of total fat supplies of world (Soya and Oilseed Bluebook 2010), because of high content of polyunsaturated fatty acids essential for human nutrition (Emken 1995). They are precursors of prostaglandins and hormones that play an important activity in the regulation of physiological and biochemical functions of human body.

The relative content of fatty acids influences the physical and chemical characteristics of the oil, thus the suitability of the oil for a particular use. 
Fatty acid composition of soybean seeds as affected by $P$ fertilization supplementation is presented in Table (4) and Fig. (4). The content of the fatty acids in seed oil responded differently to $P$ application rates of both $P$ sources. Phosphorus fertilization affects on the concentrations of palmitic and linoleic acids were significant and positive. Oleic acid responded positively to $P$ rates. Linoleic and linolenic acid levels showed significant responses to $P$ applications. There were significant differences in the concentrations of all fatty acids among the different levels of added $P$.

Israel et al., (2007) observed an increase in oleic acid concentration at higher P application rates. Krueger et al., (2013) reported that linolenic acid concentration increased with excessively high $P$ fertilization. The different results in seed quality attributes between our study and these prior investigations are possibly related to the differences in soil $P$ fertility levels, cultivar characteristics, and weather conditions among these studies. Linoleic acid concentration is a key quality attribute in soybean seed for human and animal consumption because it is an important polyunsaturated fatty acid that cannot be synthesized by humans or animals. Therefore, higher levels of linoleic acid in the oil may increase the market value of soybean seed. The results of our study suggest that linoleic acid concentration in soybean seed can sometimes be positively affected by $\mathbf{P}$ fertilization.

Table (4): Effect of $P$ sources and their application rates on fatty acids of soybean (average of two years).

\begin{tabular}{|c|c|c|c|c|c|c|c|}
\hline \multicolumn{2}{|c|}{ Treatments } & \multirow{2}{*}{$\begin{array}{l}\text { Palmitic } \\
\text { acid } \\
(16: 0)\end{array}$} & \multirow{2}{*}{$\begin{array}{c}\text { Stearic } \\
\text { acid } \\
(18: 0)\end{array}$} & \multirow{2}{*}{$\begin{array}{l}\text { Oleic } \\
\text { acid } \\
(18: 1)\end{array}$} & \multirow{2}{*}{$\begin{array}{c}\text { Linoleic } \\
\text { acid } \\
(18: 2)\end{array}$} & \multirow{2}{*}{$\begin{array}{l}\text { Linolenic } \\
\text { acid }(18: 3)\end{array}$} & \multirow{2}{*}{$\begin{array}{c}\text { Unsaturation } \\
(\%)\end{array}$} \\
\hline$P$ sources & P levels (kg P2O5/fed & & & & & & \\
\hline \multirow{3}{*}{ SSP } & $0 \mathrm{KgP} 2 \mathrm{O} 5 / \mathrm{fed}$ & 11.48 & 3.60 & 22.33 & 46.26 & 4.63 & 73.22 \\
\hline & $15 \mathrm{KgP} 205 / \mathrm{fed}$ & 12.06 & 4.14 & 22.94 & 47.58 & 5.26 & 75.78 \\
\hline & $22.5 \mathrm{KgP} 2 \mathrm{O} / \mathrm{fed}$ & 13.59 & 4.28 & 23.71 & 49.01 & 5.66 & 78.37 \\
\hline & Mean & 12.38 & 4.00 & 22.99 & 47.61 & 5.18 & 75.79 \\
\hline \multirow{3}{*}{ Rp } & $0 \mathrm{KgP} 205 / \mathrm{fed}$ & 11.45 & 3.57 & 22.43 & 46.29 & 4.69 & 73.42 \\
\hline & $15 \mathrm{KgP} 2 \mathrm{O} 5 / \mathrm{fed}$ & 11.71 & 3.66 & 22.53 & 46.49 & 4.97 & 73.99 \\
\hline & $22.5 \mathrm{KgP} 2 \mathrm{O} / \mathrm{fed}$ & 12.78 & 3.68 & 23.21 & 47.90 & 5.00 & 76.11 \\
\hline & Mean & 11.98 & 3.64 & 22.72 & 46.89 & 4.89 & 74.51 \\
\hline \multirow{3}{*}{ SSP + PSB } & $0 \mathrm{KgP} 2 \mathrm{O} 5 / \mathrm{fed}$ & 11.58 & 3.58 & 22.47 & 46.32 & 4.73 & 73.52 \\
\hline & $15 \mathrm{KgP} 2 \mathrm{O} / \mathrm{fed}$ & 13.97 & 4.67 & 24.50 & 49.51 & 6.21 & 80.22 \\
\hline & $22.5 \mathrm{KgP} 2 \mathrm{O} / \mathrm{fed}$ & 14.11 & 5.06 & 25.23 & 51.83 & 6.51 & 83.56 \\
\hline & Mean & 13.22 & 4.44 & 24.07 & 49.22 & 5.82 & 79.10 \\
\hline \multirow{3}{*}{$R p+P S B$} & $0 \mathrm{KgP2O5} / \mathrm{fed}$ & 11.52 & 3.58 & 22.50 & 46.36 & 4.76 & 73.62 \\
\hline & $15 \mathrm{KgP} 2 \mathrm{O} / \mathrm{fed}$ & 13.10 & 4.18 & 23.80 & 48.03 & 5.43 & 77.25 \\
\hline & $22.5 \mathrm{KgP} 2 \mathrm{O} / \mathrm{fed}$ & 13.70 & 4.44 & 24.67 & 49.42 & 5.87 & 79.96 \\
\hline & Mean & 12.77 & 4.07 & 23.65 & 47.94 & 5.35 & 76.94 \\
\hline
\end{tabular}


Effect of different sources of phosphorus and Bio fertilizers on yield and .............

\begin{tabular}{|c|c|c|c|c|c|c|c|}
\hline \multirow{3}{*}{ Mean } & $0 \mathrm{KgP} 2 \mathrm{O} 5 / \mathrm{fed}$ & 11.51 & 3.58 & 22.43 & 46.31 & 4.70 & 73.44 \\
\hline & $15 \mathrm{KgP} 205 / \mathrm{fed}$ & 12.71 & 4.16 & 23.44 & 47.9 & 5.47 & 76.81 \\
\hline & $22.5 \mathrm{KgP} 2 \mathrm{O} 5 / \mathrm{fed}$ & 13.55 & 4.37 & 24.20 & 49.54 & 5.76 & 79.5 \\
\hline \multirow{3}{*}{ LSD at $5 \%$} & P sources & 0.41 & 0.22 & 0.39 & 1.09 & 0.23 & - \\
\hline & P levels (kg P2O5/fed & 0.35 & 0.19 & 0.34 & 0.94 & 0.20 & - \\
\hline & Interaction & 0.71 & 0.39 & 0.67 & ns & 0.40 & - \\
\hline
\end{tabular}

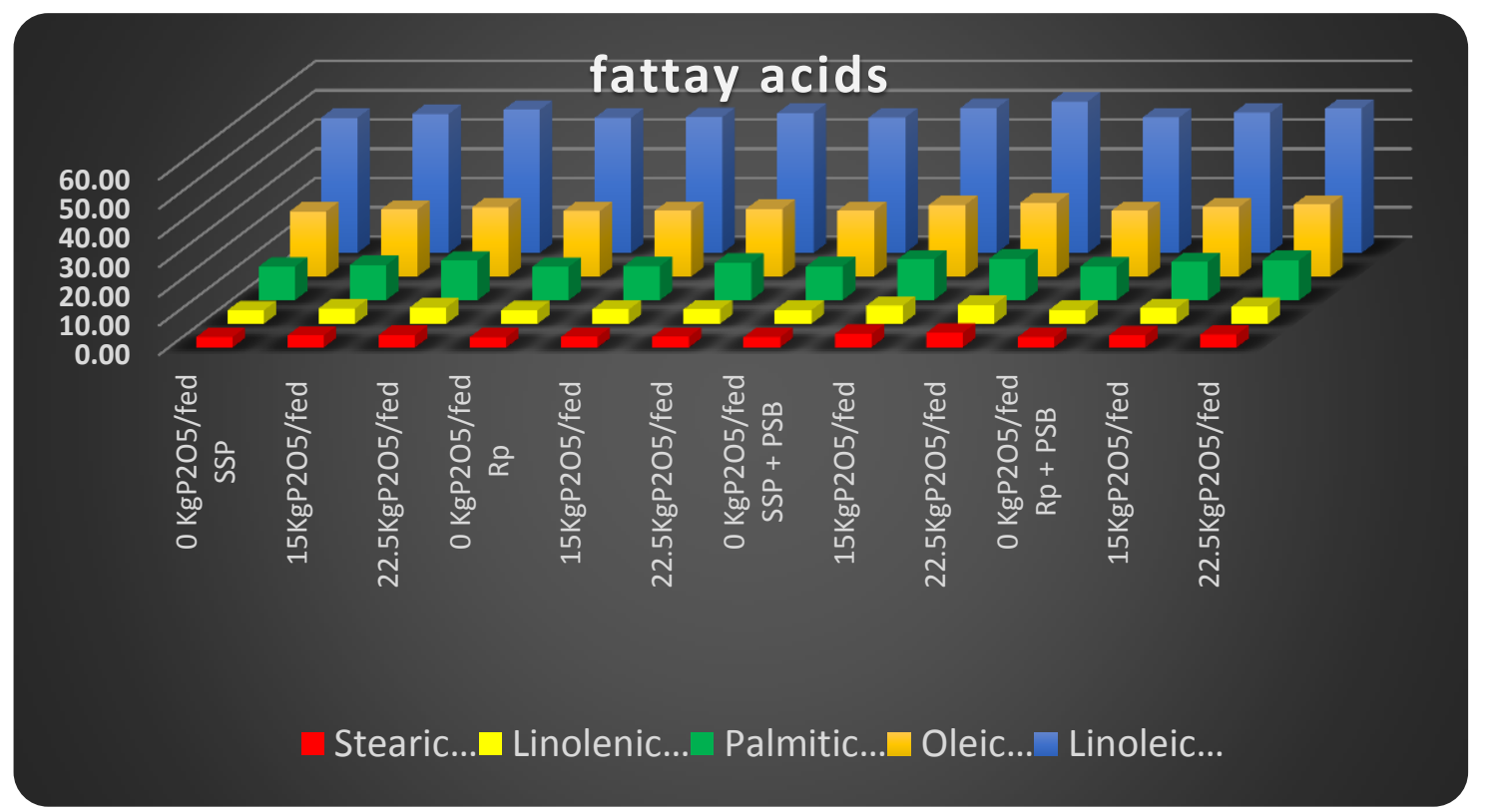

Fig. (4): Effect of P sources and their application rates on fatty acids

Interaction effect of phosphorus sources and added levels on seed quality of soybean, the results in Table (4) indicated that the application of phosphorus through SSP+PSB significantly recorded the highest oil and protein yield of soybean seed. Application of $22.5 \mathrm{KgP}_{2} \mathrm{O}_{5} / \mathrm{fed}$ with PSB significantly gave higher oil content and oil yield in soybean seeds.

\section{Effect of $P$ Sources on nutrient uptakes and efficiency}

Application of $\mathrm{P}$ at rate of $22.5 \mathrm{~kg} \mathrm{P}_{2} \mathrm{O}_{5}$ $\mathrm{fed}^{-1}$ as single superphosphate resulted in a significant increases of nitrogen uptake by soybean seeds over than those resulted from the treatment of rock phosphate and control (Table 5).
Phosphorus uptake by soybean seeds and straw increased significantly over control when $P$ applied at two rates of either SSP or RP and more increases were obtained with the combined treatment of P+PSB, This could be possible due to higher biomass production as well as due to more plant accessible phosphate made available by solubilization by PSB from native and applied phosphorus. Similar results and views were also shared by Deshpande et al., (2015) and Nusakho et al., (2015). In addition, SSP have a significant increase effect on soybean seed and straw uptake of $\mathbf{P}$ compared these resulted from RP treatments at the same application rate. Maximum P uptake by seed ( $\left.8.69 \mathrm{~kg} \mathrm{fed}^{1}\right)$ 
was found with the treatment of SSP+PSB and the lowest one was found with the control $\left(3.95 \mathrm{~kg} \mathrm{fed}^{1}\right)$. Application of rock phosphate alone also improved the $\mathrm{N}$ absorption by the soybean crop but it was less effective than that of SSP. Thus, the results showed synergistic effect of applied $P$ on nitrogen content in soybean crop (Marschener, 2003). It might be due to the beneficial effect of phosphorus on root growth and development and nodulation of soybean which led to more $\mathrm{N}_{2}$-fixation. It might be due to release of the native $P$ from the soil and increased concentration of phosphorus in soil solution which helped in early root growth and nodules formation (El-Meslawy, 2014). These observations are in agreement with those of Singh and Singh (2012b).Also, maximum of phosphorus uptake by stover was $\left(15.27 \mathrm{~kg} \mathrm{fed}^{-1}\right)$ was found with the treatment of SSP+PSB. This might be due to higher yield of stover as well as phosphorus content in stover. The increase in $P$ uptake and its consequent reflection on yield as an effect of microbial inoculations may be caused by its ability to solubilize insoluble inorganic phosphates as well as to produce a necessary phytohormone indole 3 acetic acid (Datta et al., 1982 and Piccini and Azcon 1987).

Table (5): Effect of $P$ sources and their application rates on nutrient uptake and $P$ efficiencies economics of soybean (average of two years)

\begin{tabular}{|c|c|c|c|c|c|c|c|}
\hline \multicolumn{2}{|c|}{ Treatments } & \multirow{2}{*}{$\begin{array}{c}\mathbf{N} \text { uptake in } \\
\text { seed } \\
(\mathbf{k g} / \mathrm{fed})\end{array}$} & \multirow{2}{*}{$\begin{array}{l}\text { K uptake } \\
\text { in seed } \\
(\mathrm{kg} / \mathrm{fed})\end{array}$} & \multirow{2}{*}{$\begin{array}{l}\text { P uptake } \\
\text { in seed } \\
(\mathrm{kg} / \mathrm{fed})\end{array}$} & \multirow{2}{*}{$\begin{array}{l}\text { P uptake } \\
\text { in straw } \\
(\mathbf{k g} / \mathbf{f e d})\end{array}$} & \multirow{2}{*}{$\begin{array}{c}\text { Total P } \\
\text { uptake } \\
\text { (kg/fed) }\end{array}$} & \multirow{2}{*}{$\begin{array}{c}\text { P use } \\
\text { efficiency, } \\
\text { PUE }(\%\end{array}$} \\
\hline P sources & $\begin{array}{l}\text { P levels (kg } \\
\text { P2O5/fed }\end{array}$ & & & & & & \\
\hline \multirow{3}{*}{ SSP } & $0 \mathrm{KgP} 2 \mathrm{O} 5 / \mathrm{fed}$ & 45.76 & 12.64 & 3.96 & 7.04 & 11.00 & 0 \\
\hline & $15 \mathrm{KgP} 2 \mathrm{O} / \mathrm{fed}$ & 62.03 & 16.96 & 6.11 & 12.36 & 18.48 & 49.87 \\
\hline & $22.5 \mathrm{KgP} 2 \mathrm{O} 5 / \mathrm{fed}$ & 78.72 & 21.94 & 8.95 & 14.57 & 23.53 & 55.69 \\
\hline \multicolumn{2}{|r|}{ Mean } & 62.17 & 17.18 & 6.34 & 11.33 & 17.67 & 35.19 \\
\hline \multirow{3}{*}{$\mathbf{R p}$} & $0 \mathrm{KgP} 2 \mathrm{O} 5 / \mathrm{fed}$ & 45.43 & 12.63 & 3.83 & 6.63 & 10.47 & 0 \\
\hline & $15 \mathrm{KgP} 205 / \mathrm{fed}$ & 50.68 & 13.86 & 4.67 & 8.86 & 13.53 & 20.4 \\
\hline & $22.5 \mathrm{KgP} 2 \mathrm{O} 5 / \mathrm{fed}$ & 58.43 & 15.93 & 5.43 & 11.51 & 16.94 & 28.76 \\
\hline \multicolumn{2}{|r|}{ Mean } & 51.51 & 14.14 & 4.64 & 9.00 & 13.65 & 16.39 \\
\hline \multirow{3}{*}{$\begin{array}{c}\text { SSP + } \\
\text { PSB }\end{array}$} & $0 \mathrm{KgP} 2 \mathrm{O} 5 / \mathrm{fed}$ & 46.01 & 12.47 & 3.95 & 6.99 & 10.93 & 0 \\
\hline & $15 \mathrm{KgP} 2 \mathrm{O} / \mathrm{fed}$ & 87.77 & 25.60 & 9.00 & 12.83 & 21.83 & 72.67 \\
\hline & $22.5 \mathrm{KgP} 2 \mathrm{O} 5 / \mathrm{fed}$ & 90.75 & 27.46 & 10.85 & 18.49 & 29.34 & 81.82 \\
\hline \multicolumn{2}{|r|}{ Mean } & 74.84 & 21.84 & 7.93 & 12.77 & 20.70 & 51.50 \\
\hline \multirow{3}{*}{$\begin{array}{l}\text { Rp + } \\
\text { PSB }\end{array}$} & $0 \mathrm{KgP} 2 \mathrm{O} 5 / \mathrm{fed}$ & 45.23 & 12.57 & 4.04 & 7.53 & 11.57 & 0 \\
\hline & 15KgP2O5/fed & 77.19 & 21.53 & 7.53 & 11.03 & 18.56 & 46.6 \\
\hline & $22.5 \mathrm{KgP} 2 \mathrm{O} 5 / \mathrm{fed}$ & 79.44 & 23.71 & 9.54 & 16.50 & 26.04 & 64.31 \\
\hline \multicolumn{2}{|r|}{ Mean } & 67.29 & 19.27 & 7.04 & 11.69 & 18.72 & 36.97 \\
\hline
\end{tabular}


Effect of different sources of phosphorus and Bio fertilizers on yield and .............

\begin{tabular}{|c|c|c|c|c|c|c|c|}
\hline \multirow{3}{*}{ Mean } & $0 \mathrm{KgP} 2 \mathrm{O} 5 / \mathrm{fed}$ & 45.61 & 12.58 & 3.95 & 7.05 & 11.00 & 0 \\
\hline & $15 \mathrm{KgP} 2 \mathrm{O} / \mathrm{fed}$ & 69.42 & 19.49 & 6.83 & 11.27 & 18.10 & 47.39 \\
\hline & $22.5 \mathrm{KgP} 2 \mathrm{O} 5 / \mathrm{fed}$ & 76.83 & 22.26 & 8.69 & 15.27 & 23.96 & 57.65 \\
\hline \multirow{3}{*}{$\begin{array}{c}\text { LSD at } \\
5 \%\end{array}$} & P sources & 10.32 & 3.02 & 1.05 & ns & 3.46 & - \\
\hline & $\begin{array}{c}\text { P levels (kg } \\
\text { P205/fed }\end{array}$ & 8.94 & 2.61 & 0.9 & 2.72 & 3.00 & - \\
\hline & Interaction & ns & 5.23 & 1.81 & ns & ns & - \\
\hline
\end{tabular}

Effect of added $P$ rates on nutrient uptake by soybean and its efficiency

Application $P$ at a rate of $22.5 \mathrm{KgP}_{2} \mathrm{O}_{5}$ /fed., either SSP or RP resulted in a significant increase of nitrogen $\left(78.72 \mathrm{~kg} \mathrm{fed}^{-1}\right)$, phosphorus $\left(8.954 \mathrm{~kg} \mathrm{fed}^{-1}\right)$ and potassium $(21.94 \mathrm{~kg}$ fed $^{1}$ ) uptake by the seed compared with the control treatment. The increased uptake of phosphorus was due to added supply of nutrients and well developed root system resulting in better absorption of water and nutrient. More improvement in uptake of nutrients due to combined application of $P$ and PSB resulted in improved $P$ availability which played a pivotal role in development of roots (Dadhich et al., 2011 in Soybean -wheat cropping sequence).

Phosphorus uptake by soybean increases with increasing added rate of phosphorus. Maximum phosphorus uptake was obtained the treatment of $22.5 \mathrm{~kg} \mathrm{P}_{2} \mathrm{O}_{5}$ fed $^{-1}$ as SSP with PSB and the lowest was obtained from the control (Table 5). Kumar and Kushwaha (2006) reported that $\mathbf{P}$ uptake by pigeon pea significantly increased with increasing added $P$ due to higher amount of biomass production and subsequently greater phosphorus accumulation by the plant. In the same trend phosphorus use efficiency was also increased by increasing phosphorus level up to $\mathbf{2 2 . 5}$ kg $\mathrm{P}_{2} \mathrm{O}_{5} \mathrm{fed}^{-1}$ and declined at lower level.
The maximum PUE (81.82 \%) was observed at $22.5 \mathrm{~kg} \mathrm{P}_{2} \mathrm{O}_{5}$ fed $^{-1} \mathrm{P}$ rate for SSP+PSB and it decreased at lower $P$ rates. Similarly, the maximum PUE of $64.31 \%$ was observed at $22.5 \mathrm{~kg} \mathrm{P}_{2} \mathrm{O}_{5}$ fed $^{-}$ ${ }^{1} \mathrm{P}$ rate for $\mathrm{RP}+\mathrm{PSB}$ and it decreased at lower $\mathbf{P}$ rates. Results are in conformity with those of Rahim et al., (2010), who concluded that wheat growth increased significantly with the use of $P$. However, it is clear from Table (5) that elevated $P$ application has significant influence on the PUE of soybean plant.

\section{CONCLUSIONS}

From the above-mentioned results, it can be inferred that application of SSP+PSB significantly proved effective in enhancing yield attributes and yield of soybean. Similarly, phosphorus use efficiency was higher with applying SSP+PSB. The growth, yield attributes and yield were increased with increasing phosphorus levels. Phosphorus application rates had greater impacts on leaf nutrition at the earlier growth stages. Protein, oil, and fatty acid concentrations in seed responded differently to $P$ fertilization. In general, protein and oil concentrations were enhanced with increased $P$ application rate. Palmitic and oleic concentrations responded positively to $P$ application rate up to higher $P$ application rate. However, the response of linolenic acid concentration was inconsistent (negative or positive). Stearic concentration was influenced by $\mathrm{P}$ fertilization. Application of $22.5 \mathrm{~kg} \mathrm{P}_{2} \mathrm{O}_{5}$ 
$\mathrm{fed}^{-1}$ resulted in higher production of protein and palmitic, oleic, and linolenic acids than control. Excessive $P$ application rates could give higher seed yield and improve the quality of some attributes in seed. Our results suggest that linoleic acid concentration, a key quality attribute in soybean seed for human and animal consumption, can sometimes be enhanced by $P$ fertilization, and thus appropriate $P$ application may increase the market value of soybean production.

\section{REFERENCES}

Abdelhameid, N.M. (2018). Synergistic interaction of bradyryizobiom and arbuscular mycorrhizal fungi with levels of mineral nitrogen, phosphorous molybdenum on peanut grown in sandy soils. Menoufia J. Soil Sci., 3 (December):333-349.

Abou Hussien, E.A., W.M. Nada and M. Kh. Elgezeuri (2017). Evaluation on efficiency of sulphur fertilizer in calcareous soil manured by compost. Menoufia J. Soil Sci., 2 (February): 5970.

Afzal, A., M. Ashraf, A. Saeed and M. Farooq (2005). Effect of phosphate solubilizing microorganisms on phosphorus uptake, yield and yield traits of wheat (Triticum aestivum L.) in rainfed area. Int. J. Agri. Biol., 7(2): 207-209.

Ahmed, E., A .O. Hassan and E.Y.A. Raddad. (2015). Effect of different Phosphorus sources and methods of application on growth, nodulation and yield of soybean (Glycine max (L) Merr.) Open American J. of Agric. Res. $2(1): 1-7$.

Ali, M .A. A. Ali, M.I. Ahmad, S.W. Hassan, S.R. Khan and Ali A Abid (2014). Phosphorus effects on growth and yield parameters of mungbean. Sci. Int. (Lahore), 26(4): 1821-1824.
A.O. A. C. (1990). Official Method of Analysis. Association of Official Analytical Cereal Chemists. Washington, DC, USA.

Basak, R.K. (2006). 'Fertilizers". Kalyani Publishers, Ludhiana- New Delhi Noida (U.P.) Hyderabad-ChiennaiCalcutta-Cuttack.

Brady, N. C. (2002). Phosphorus and Potassium. In: The Nature and Properties of Soils. (pp. 352). Prentice - Hall of India, Delhi.

Cao, N.D., B.T. Nguyen and T.P.N. Van (2017). Effects of Bradyrhizobia and Phosphate-solubilizing bacteria on soybean (Glycine max L. Merrill) cultivated on Ferrasols of Cujut district, DakNong province, Vietnam. Inter. J. Envir. \& Agric.Res., (3):70-79.

Chapman, H.D. and P.F. Pratt (1978). "Methods of Analysis for Soils, Plants and Waters", 309 p., Division of Agric. Sci., Univ.California, Berkeley, USA.

Chen, Y. P., P. D. Rekha, A. B. Arunshen, W. A. Lai and C. C. Young (2006). Phosphate solubilizing bacteria from subtropical soil and their tricalcium phosphate solubilizing abilities. Appl. Soil Ecol. (34): 33-41.

Cherry, J. H., L. Bishop, P. M. Hasegawa and H. R. Leffler (1985). Differences in the fatty acid composition of soybean seed produced in northern and southern areas of the U.S.A. Photochemistry (24): 237-241.

Dadhich, S. K., L. L. Somani and D. Shilpkar (2011). Effect of integrated use of fertilizer $P$, FYM and bio fertilizers on the soil properties and productivity of Soybean-Wheat crop sequence. J. Adv. Dev. Res., 2(1): 4246.

Datta, M., S. Banik and R.K. Gupta (1982). Studies on the efficacy of a phytohormone producing phosphate solubilizing Bacillus firmus in 
augmenting paddy yield in acid soils of Nagaland. Plant Soil, 69: 365-373.

Deshpande, A. N, S.S. Dalavi, S.H. Pandey, V.P. Bhalerao and A.B. Godavi (2015). Effect of rock phosphate along with organic manures on soil properties, yield and nutrient uptake by wheat and chickpea. J. of the Indian Soc. of Soil Sci., 63(1): 93- 99.

Deubel, A. and W. Merbach (2005). Influence of Microorganisms on Phosphorus Bioavailability in Soils. In: F. Buscot and A. Varma (Eds.), Microorganisms in Soils: Roles in Genesis and Functions. SpringerVerlag, Berlin Heidelberg, Germany. p. 62.

Dubey, S.D., P. Shukla and S.P. Tiwari (1997). Effect of $S$ fertilizer on growth yield of linseed (Linum usitatissium L.). Indian J. of Agric. Sci. 67(11): 539540.

Dwivedi, A.K. and P.N. Bapat (1998). Sulphur-phosphorus interaction on the synthesis of nitrogenous fraction and oil in soybean. J. Indian Soci.of Soil Scie; 46:254-257.

EI -Meslawy, A.I.S. (2014). Effect of bioorganic amendments on phosphorous solublization in soils. M.Sc. Environment Studies and Research Institute, University of Sadat City.

Emken, E. A. (1995). Physiochemical properties, intake, and metabolism. Am. J Clin. Nutr. (62): 659-669.

Erman, M., B. Yildirim, T. Necat and C. Fatih (2009). Effect of phosphorus application and Rhizobium inoculation on the yield, nodulation and nutrient uptake in field pea (Pisum sativum sp. arvense L.). J. Animal and Veter. Adv., 8(2): 301-304.

Galal, Y. G., J. A. El-Gandaour and F. A. El-Akel (2001). Stimulation of Wheat Growth and N-Fixation Through Azospirillum and Rhizobium
Inoculation. A field trial with $15 \mathrm{~N}$ techniques, 666-667. In. (W.J. Horst. Eds.).Plant Nutrition- Food Security and Sustainability of Agroecosystems.

Gomez, K. A. and A. A. Gomez (1984). Statistical Procedures for Agricultural Research, An International Rice Research Institute Book, Wiley- Inter Science Publication, New York, USA, 680.

Goodroad, L. L. and M. D. Jellum (1988). Effect of $\mathrm{N}$ fertilizer rate and soil $\mathrm{pH}$ on $\mathrm{N}$ efficiency in corn. Plant and Soil, 106: 85-89.

Havlin, L. J., D. J. BeatonL, S. Tisdale and L. W. Nelson (1999). Soil fertility and fertilizers. Prentice Hall of Indian. $\left(6^{\text {th }}\right.$ ed., pp. 220, 227, 228, 319-346).

Hou, A., P. Chen, J. Alloatti, D. Li, L. Mozzoni, B. Zhang and A. Shi (2009). Genetic variability of seed sugar content in worldwide soybean germplasm collections. Crop Sci., 49: 903-912.

llbas, A. I. and S. Sahn (2005). Glomusfasciculatum inoculation improves soybean production. ActaAgriculture- Scandinavia - section $B$, soil and plant sciences. India, 55(4): 287-292.

Israel, D.W., P. Kwanyuen, J.W. Burton and D.R. Walker (2007). Response of Low Seed Phytic Acid Soybeans to Increases in External Phosphorus Supply. Crop Science, 47: 2036- 2046.

Jain, A.K., S. Kumar and J.D.S. Panwar (2007). Response of mungbean (Vigna radiata) to phosphorus and micronutrients on $\mathrm{N}$ and $\mathrm{P}$ uptake and seed quality. Legume Research, 30 (3): 201-204.

Jain, P.C. and S.K. Trivedi (2005). Response of soybean (Glycine max L.) to phosphorus and bio fertilizers. Legume Research, 28(1): 30-33.

Kandpal, B. M. and A. S. Chandel (1993). Effect of gypsum and pyrites as 
sources of sulphur on nitrogen fixation, dry matter yield and quality of soybean (Glycine max). Indian J. of Agron., 38: 137-139.

Khan, K. S. and R. G. Joergensen (2009). Changes in microbial biomass and $P$ fractions in biogenic household waste compost amended with inorganic $P$ fertilizers. Bioresour. Technol.100: 303-309.

Klute, A.A. (1986). 'Methods of Soil Analysis". American Society of Agronomy, Inc. Publishers, Madison, Wisconsin, U.S.A., $2^{\text {nd }}$ Edition.

Krueger, K., A.S. Goggi, A.P. Mallarino and R.E. Mullen (2013). Phosphorus and potassium fertilization effects on soybean seed quality and composition. Crop Science, 53: 602610

Kumaga, F. K. and K. Ofori (2004). Response of soybean to Bradyrhizobia inoculation and phosphorus inoculation. Int. J. Agric. and Bio. 6(2): 324-327.

Kumar, A. and H. S. Kushwaha (2006). Response of pigeon pea (Cajanuscajan) to sources and levels of phosphorus under rainfed condition. Indian Journal of Agronomy, 51(1): 60-62.

Liu, K. (1997). Soybeans Chemistry, Technology and Utilization. Chapman \& Hall, New York.

Marschner, H. (2003). "Mineral Nutrition of Higher Plants "Academic Press, Harcount Brace Janovisch Publishers. New York.

Masuda, T. and P.D. Goldsmith (2009). World Soybean Production: Area Harvested, Yield, and Long-Term Projections. International Food and Agribusiness Management Review, 12: 143-163.

Miller, R.W., R.L. Danhaue and J.U. Miller (1990). "An Introduction to Soil and Plant Growth". Sixth ed., Published
Prentice Hall International Inc., London, 269-279.

Nusakho, N., Y.K Sharma, S.K. Sharma and R.C. Gupta (2015). Effect of phosphorus and phosphorus solubilizing bacteria on performance of green gram and soil properties. Annals of Plant and Soil Research, 17(3): 323-325.

Page, A. L., R. H. Miller and D. R. Keeny (ed.) (1982). Methods of Soil Analysis, part2. Chemical and Microbiological Properties. Amer. Soc. of Agronomy. Madison, Wisconsin, USA.

Piccini, D. and R. Azcon (1987). Effect of phosphate solubilizing bacteria and vesicular arbuscular mycorrhizal fungi on the utilization of Layover rock phosphate by alfa alfa plants using a sand vermiculite medium. Plant Soil, 101: 45-50.

Qasim Shahid M., M. F. Saleem, H. Z. Khan and S. A. Anjum (2009). Performance of soybean (glycine max I.) Under different phosphorus levels and inoculation. Pak. J. Agri. Sci., 46(4): 237- 241.

Rahim, A., A.M. Ranjah, Rahamtullah and E.A. Waraich (2010). Effect of phosphorus application and irrigation scheduling on wheat yield and phosphorus use efficiency. Soil Sci. Soc. Pak., 29: 15-22.

Richardson, A.E. (2001). Prospects for using soil microorganisms to improve the acquisition of phosphorus by plants. Aust J. Plant Physiol 28: 897906.

Schnebly, S. R. and W. R. Fehr (1993). Effect of years and planting dates on fatty acid composition of soybean genotypes. Crop Sci., 33: 716-719.

Shah, P., K. M. Kakar and K. Zada (2002). Phosphorus Use Efficiency of Soybean as Affected by Phosphorus Application and Inoculation. In (W.J. Horst. Eds.). Plant Nutrition-Food 
Security and Sustainability of Agro ecosystems, 670-671.

Sharma, S. C., A. K. Vyas and M. S. Shaktwat (2002). Effect of levels and sources of phosphorus under the influence of FYM on growth determinants and productivity of soybean. Indian J. Agric. Res., 36(2): 123-127.

Singh, A.K. and R.S. Singh (2012b). Effect of phosphorus and bio inoculants on yield, nutrient uptake and economics of long duration pigeon pea (Cajanus cajan). Indian J. of Agronomy, 57 (3): 265-269.

Singh, S., H. Singh, J. Singh and V.K. Sharma (2014). Effect of integrated use of rock phosphate, molybdenum and phosphate solubilizing bacteria on lentil (Lens culinaris) in an alluvial soil. Indian Journal of Agronomy 59(3): 433-438.

Soya and Oilseed Bluebook (2010). The Annual Directory of the Word Oilseed Industry, Bar Harbor, ME, USA: Soyatech, pp 324-25.

Taiz, L. and E. Zeiger (1991). Plant Physiology: Mineral Nutrition, The Benjamin Cummings Publishing Co., Inc. Redwood City, CA.

Tapas, C. and S. B. Gupta (2005). Effect of bacterial fertilizers with different phosphorus levels on soybean and soil micro flora. Advances in Plant Sciences, Raipur, India, 18(1): 81-86.
Tomar, S. S., P. C. Jain and R. L. Agarwal (2006). Effect of nutrient management practices on yield and quality of soybean. Res. Crops, 7(1): 96-99.

Tomar, S. S., R. Singh and P. S. Singh (2004). Response of phosphorus, sulphur and Rhizobium inoculation on growth, yield and quality of soybean. Prog. Agric., 4(1): 72-73.

Wilson, L. A. (1995). Soy Foods. In: Practical Handbook of Soybean Processing and Utilization, D. R. Erickson (Ed.) 428 - 459. AOCS Press, Champaign, IL and United Soybean Board, St. Louis, MO

Wilson, R. F. (2004). Seed Composition. In: Soybeans: Improvement, Production, and Uses. $3^{\text {rd }}$ edition, $\mathrm{H}$. R. Boerma, \& J. E. Specht, (Eds.), 621669. ASA Monogr. 16. ASA, Madison, WI.

Yin, X.H., N. Bellaloui, A.M. McClure, D.D. Tyler and A. Mengistu (2016). Phosphorus fertilization differentially influences fatty Acids, protein, and oil in soybean. American J. Plant Sci., (7): 1975-1992.

Zaidi, A., M.S. Khan, M. Ahemad, M. Oves and P.A. Wani (2009b). Recent advances in plant growth promotion by phosphate-solubilizing microbes. In: Khan MS et al (Eds) Microbial Strategies for Crop Improvement. Springer-Verlag, Berlin Heidelberg. Pp. 23-50. 
تأثثير مصادر مختلفة من الفوسفور والتسميد الحيوى على المحصول وجودة بذور فول الصويا

لمياء عبدالحليم عبدالرحمن، داليا عدروزسيد، ماجدةعلى عويس

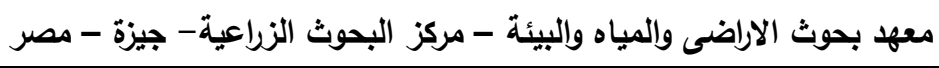

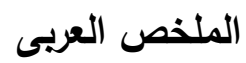

أجريـت تجريتـان حقليتـان بمزرعـة محطـة البحوث الزراعيسه بـالجميزة - محافظه الغربيـة- مصر خـلال الموسـين

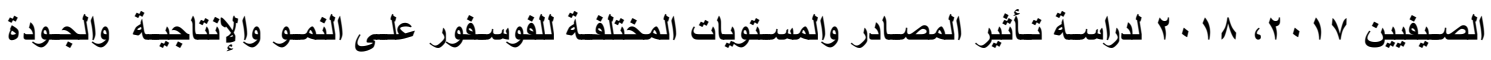

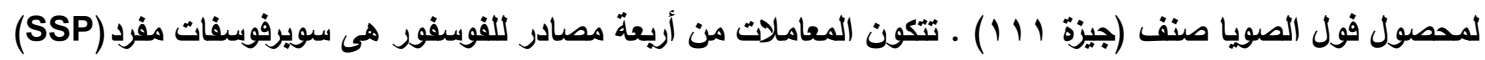

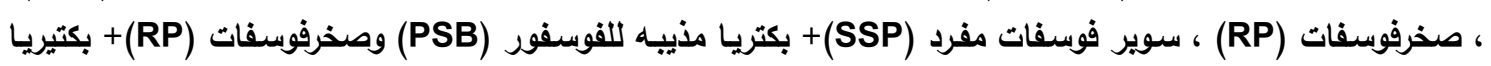

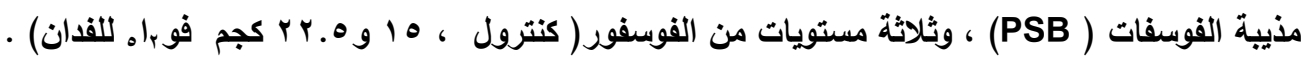

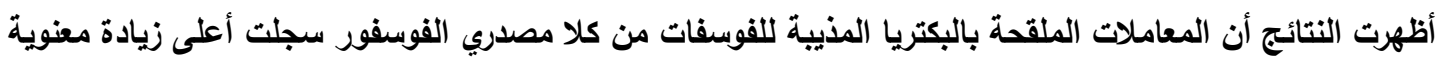

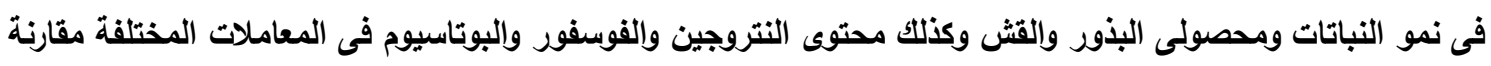

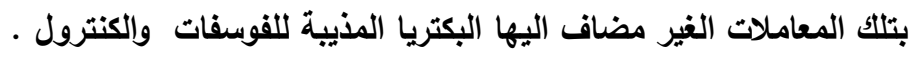

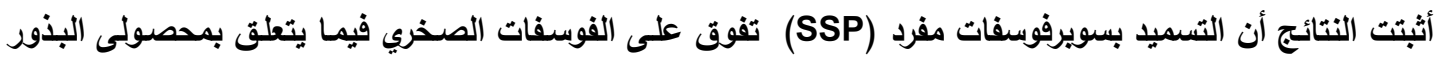

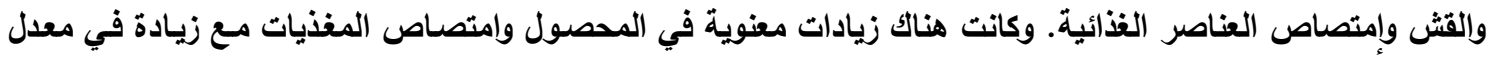

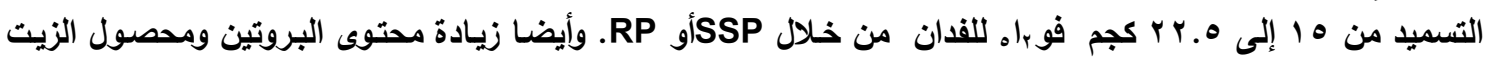

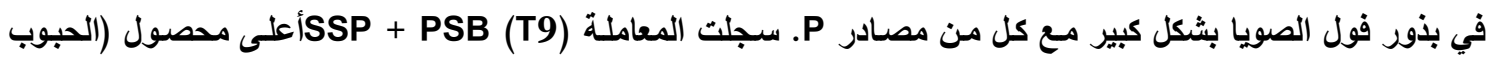

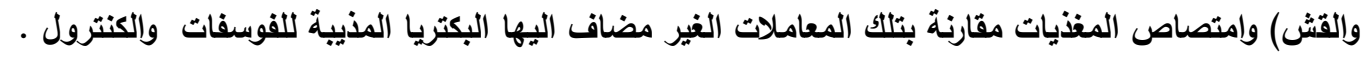

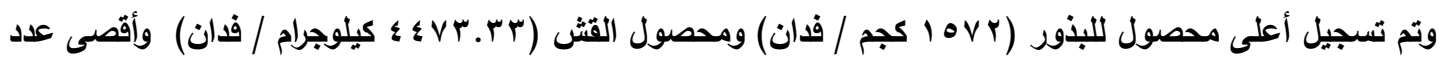

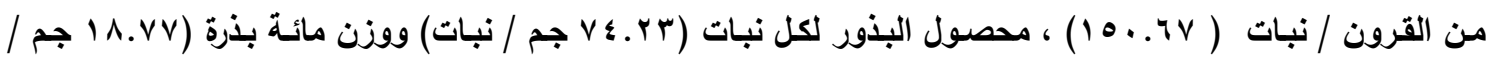

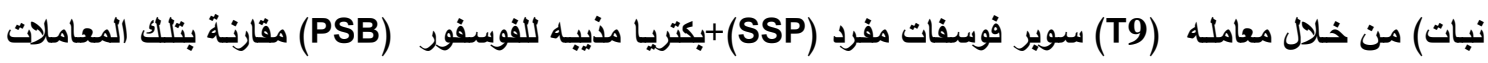
الغير مضاف اليها البكتريا المذيبة للفوسفات ولنات والكنترول.

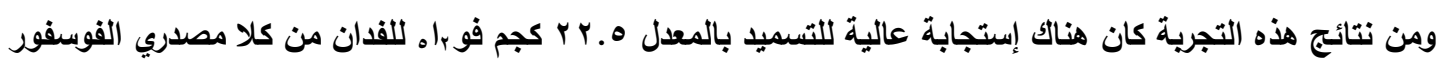

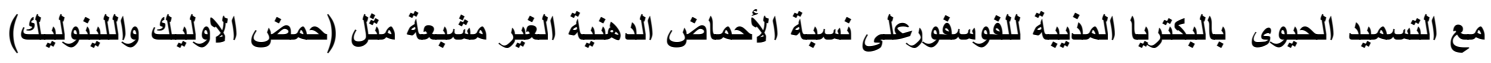

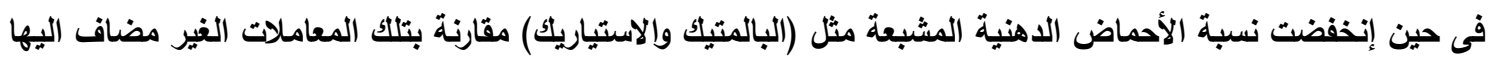


البكتريا المذيبة للفوسفات والكتترول ـ فيما يتعلق بتقييم كفاءة إستخدام التسميد بمصادر الفسفور كانت هناك تأثيرات أكثر وضوحًا عذد الإستخدام المثترك لسوير فوسفات مفرد + بكتريا مذيبة للفوسفور يليها صخرفوسفات (RP)+ بكتيريا مذيبة الفوسفات.

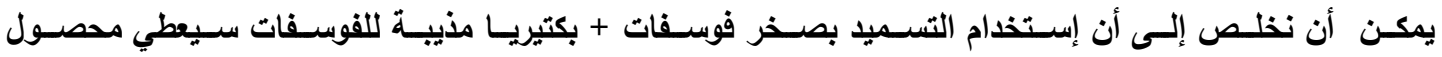

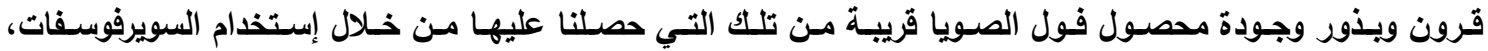

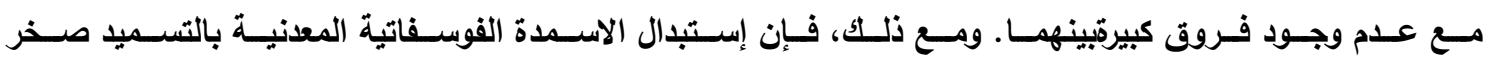
فوسفات + بكتيريا مذيبه للفوسفات سيساعد في الد من التلوث البيئي وإنتاج غذاء إنساني آمن.

السادة المحكمين

أ.د/ عيسوى قاسم محمود كلية الزراعة - جامعة طنطا ، أ.د/ الحسينى عبد الغفار أبو حسين كلية الزراعة - جامعة المنوفية 